\title{
Green Marketing and Benefits to Business
}

\author{
Yakup Durmaz ${ }^{1}$, Hatice Vildan Yaşar ${ }^{2}$ \\ ${ }^{1}$ Hasan Kalyoncu University, Department of Marketing, Havalimanı Yolu 8. Km Sahinbey, Gaziantep, Turkey \\ ${ }^{2}$ Hasan Kalyoncu University, Phd Student. Havalimanı Yolu 8. Km Sahinbey, Gaziantep, Turkey \\ Correspondence: Yakup Durmaz, Hasan, Kalyoncu University, Department of Marketing.
}

\author{
Received: May 9, 2016 Accepted: May 11, 2016 Online Published: May 21, 2016
}

doi:10.11114/bms.v2i2.1624

URL: http://dx.doi.org/10.11114/bms.v2i2.1624

\begin{abstract}
Nowadays, businesses are aware that they cannot carry on without being aware of environmental problems. Businesses have to take environmental aspects of all activities in their business strategies and long-term plans. Those environmental activities and green marketing are started to be taken into consideration by so many businesses. In this study, green marketing is examined.
\end{abstract}

Keywords: environment, business, green marketing

\section{Introduction}

It is observed that the concept of environment and viewpoints about the environment- in parallel with results of social, economic, political developments and environmental problems- considerably undergo a change in recent years. Chimney gasses, toxic waste, and other waste which occur as the result of industrialization which has started in England with the industrial revolution and continued with advancing in other Western countries cause serious environmental problems. While ambitious and unrestrained production desire cause waste of sources, fabrication waste, and consumption waste have started to pollute atmosphere, seas, rivers and lands internationally. In the beginning of 21.century, this pollution prompted to countries for searching internationally binding solutions about how the world is going to be cleaned. With the aim of being protected by environmental threats of rapid development and unrestrainedly increasing trade, international environmental organizations have started to come up in the second half of the 19.century.

Nowadays, businesses in any field have understood that they cannot carry on without being sensitive towards environmental problems. Accordingly, businesses have to take into consideration environmental issues while they prepare their strategies and long-term plans because, in any market, environmental awareness provides a competitive advantage yet. In that point, green marketing concept has occurred in both industry and service industries and with the help of support and pressure of consumers, stakeholders and government, businesses enter into the new process.

In this study, green marketing concept has examined theoretically.

\section{Green Marketing Concept}

Green marketing concept which has entered in the 1980s marketing literature is used synonymously with ecologic, environmentalist or environmental marketing, sustained marketing concepts (Ay and Ecevit, 2005). Green marketing has discussed and identified in "ecologic marketing" seminar prepared by American Marketing Association in 1975 for the first time. According to this identification, ecologic marketing is studies which are related marketing activities' positive and negative effects of environmental pollution, energy consumption and other sources consumption (www.paradoks.org/erbaslar).

Green marketing is fulfillment needs and wishes of the consumers with an environment-friendly approach. Because one the most important factor of green marketing idea adoption by businesses is consumer's environmental consciousness increase and tendency to prefer Eco credential products. Besides, because of some reasons such as government policies, environmentalist associations' pressure, green marketing idea is developed in businesses. Green marketing understanding has increased with the realization of its' competitive advantage and dramatically low costs (Eren and Yilmaz, 2008).

Kotlar and Zaltman (1971) identify green marketing in the social marketing. In this context, social marketing is identified as creating marketing content and techniques in social benefits context without commercial concern. 
Kotler (1991) identifies green marketing under the societal marketing concept as a process which protects and develops consumer's and society welfare, specifies organization's needs, wishes and intended population's interests and provides more productive and effective customer satisfaction for the firm than its' rival firms.

Polonsky (1994) identifies green marketing as fulfilling needs and wishes of the consumers with the least damage. In a research (EPANSW), 1994 in Australia, it is stated that \%80 percent of the consumers' buying behaviors have changed because of the environmental reasons (Polonsky, 1994). According to a study conducted by Polonsky et al. in England, \%78 percentage of the 50 biggest firm managers of England state that environmental issues have an important place in work activities and $\% 82$ percentage of them state that these issues are going to be more important in the future (Polonsky et al., 1998).

\subsection{History of Green Marketing}

So many technological and business implementations used through 20.century damage the ecosystem and it causes problems such as toxic pollution, the decrease in forest and green-field, soil erosion, biodiversity extinction (Ottman et al. 2006).

In the history of green marketing, ecologic marketing, environmentalist marketing, green marketing and sustained marketing concepts should be discussed altogether. Ecologic marketing is used in the strict sense to define some environmental problems such as pollution, energy sources extinction and marketing activities to prevent these ones with the existing technology. In environmentalist and green marketing concepts, there is an administrative perspective which involves broader product category and philosophy (Ay and Ecevit, 2005).

Sustainable marketing reflects discussion of marketing activities with macro outlook and in the context of sustainable development understanding. For the consumers environmentalism is identified as " awakening time" in the 1960s, "time to make the move" in 1970s, "time for being economic" in 1980s and "power on the market" in 1990s. That change has very different effective stages on marketing discipline (Peattie,2001; Akt. Canım, 2015).

\section{First Stage: Ecologic Marketing}

Origin of the ecologic marketing dates to social and environmental concerns which occur at the beginning of the 60s and 70s. Thoughts of that period foresee that no controllable growth will waste natural resources and system that we need and they focus on the earth on which we live will have an end. That stage focuses on some specific problems such as air pollution, petroleum reserves consumption, petroleum waste and ecologic effects of synthetic pesticides. So it has the narrow point of view. It is tried to be specified products, businesses, industries which cause problems or can help for the solutions. In this period, discussions continued in a narrow area such as automotive, petrol and industries which produce synthetic chemicals for agricultural production. It is not seen any significant changes in the behaviors of producers and consumers (Peattie, 2001; Akt. Canım, 2015).

\section{Second Stage: Environmentalist Marketing}

The second stage of green marketing has occurred towards to end of the 1980s. This stage is the period that today's modern green marketing principals have occurred and developed. A range of events and discoveries attract the attention of the defenselessness of the people and nature. Bhopal disaster named as the worst chemical disaster in the world in 1984, Chornobyl catastrophe in 1986, environmental pollution caused by Exxon-Valdes tanker in 1989 and discovered ozone layer depletion in 1995 are the events that start the change. Conducted studies in the 90s in the USA reveal that the large part of the consumers are ready for paying to greener products. The thought which is about green marketing is not for only an industry, it is applicable to all forms of production and consumption industries is the name of this second stage (Özata, 2009).

\subsubsection{Green Marketing Implementations in the World}

Dirty environment as the result of developing technology, increasing overpopulation and changing consumptions habits has started to threatened human health and natural environment. The countries which realize this situation and decide to take measures have signed the Kyoto Protocol. Kyoto Protocol is the most concrete and the only international environmental protocol which is about global warming and climate change. With that protocol, it is aimed to balance greenhouse gasses density in the level of safety for the climate. It is also planned to be signed by the countries which have signatures in United Nations Framework Convention on Climate Change (unfccc) under the control of United Nations. On the other hand, some private companies such as Body Shop, Ecover, Volvo, 3M and Mc Donald's are the leading companies which adopt green marketing as a part of their business' strategies (Canım, 2015). Procter \& Gamble firm use \%100 recyclable plastic containers for their Spic and Span products (Canım, 2015). Stonyfield farm is the first American dairy that pays money to their farmers with the aim of preventing feeding their animals with artificial growth hormone RGBH. That farm is the first producer which decreased its' establishments' hydrogen emission totally for preventing global warming (Canım, 2015). 
Recently, Hp which is one of the 10 greenest companies according to world-famous Fortune magazine has announced that it started to use implementations that decrease the green gas effect in its regulations on ink, toner, and packages. Approximately works on the environmental issues over 20 years, HP focuses on the energy efficiency issue which is an inseparable part of its' environmental program and especially on the using the energy efficiently (www.çevreciyiz.com).

Germany, the leader of the green movement and the country which has the harshest standard among European countries, gets off the ground of Blue Angel implementation which is the essence of environmental label system since 1978. Besides since 1993, package containers such as yogurt and beverage containers are gathered by retailers (Canım, 2015). Big food retailers such as Migros and Coop establish boxes for the waste packages. In Switzerland in each Kanton, municipalities sell stamps valuing 3 Frank (approximately 3.5 Turkish Liras) for sticking on the special garbage bags distributed by municipalities. After the consumers separate garbage for throwing them on the separated special boxes out of the city as plastic, glass, paper, battery and electronic, they throw the rest of the garbage by using those special bags with the stamps. Nonobservant people are penalized with huge costs. In 1977 under the leadership of 27 experts, Scientific Researches Institute was founded with the aim of conducting scientific researches in the area of ecology and finding solutions for the polluted environment. Today this institute has expanded in three different states (Freiburg, Darmstadt, Berlin) of Germany with its 70 scientist and 100 workers and with its studies and projects; it has become a big institute followed by all Europe (www. Oeko.de). Now in this institute, it is worked on 150 projects about protection of the ecologic environment and taking corrective measures for it. One of those projects is named as "Green Goal" that is run together with German football association and it has some criteria such as waste, transportation, energy and water consumption. This project was in 2006 World Championship, 24 countries participated in, 64 matches were played and it is predicted that approximately 3.2 million people watched it (www.greengoal.fifaworldcup.de). Another study which the Eco-Institute run together with Social and Economic Researches Institute (ISOE) is EcoTopTen. It is aimed at this project that identifying products which are environment-friendly and care about consumers health, introducing these products to the people and increasing the consumption of these products. It is also aimed to inform the people much more about ecology and environment and raising awareness (www.oeko.de). In Germany with the prepared laws, after they are used, electronic devices which have toxic effects are taken back for a fee by the producing company. So IBM Company designed and produced environmental friendly electronic devices without toxic effects and increase its' profit. Also, BP Amaco has launched a worldwide project called "Clean Fuels, Clean Cities" including 40 cities with the aim of preventing air pollution in 2000. Mercedes-Benz equipped its' buses with eco-friendly engines. Honda Motor Co which promises setting up the environmental management system and ISO 14001 and following green factory strategy achieved to receive that certificate in previous years (Dereli and Baykasoğlu, 2002).

\subsubsection{Green Marketing Practices in Turkey}

Turkey is a candidate country to EU and this situation has delayed the environmental standards applications and adoption of industrial enterprises' manner of the rule to these standards. On the contrary, practices such as CE, ISO 14000, ISO 14301 " Environmental Economic Performance Evaluation" which defines environmental criteria and green dot confront the businessmen as non-tariff barriers while the products go to EU. So many industrial enterprises which do not want to lose competitiveness in that important market have to adapt themselves to CE and ISO 14000 criteria despite all rigours (www.tobb.org.tr).

Recycling has great importance in green marketing and practices about this issue increasingly continue in our country as well. For example; for the electronic waste which is a problem, Electronic Waste Recycling Area provides service by TÜRÇEK (Turkish Environmental \&Woodlands Protection Society) in Kadıköy/İstanbul. There is another implementation which is so similar with the one in Germany and Switzerland. People pick the waste in different bags distributed by the municipality and this implementation bring off in Muğla with the support of Municipality and Environment Provincial Directorate (Uysal, 2007).

In our country, Arçelik A.Ş believes that economic development should be provided by the sustainable and eco-friendly approach and aims to protect the environment, ecologic balance and provide sustainability of the natural sources in each stage of their production. It states that they develop themselves always in this area. With this attitude, it is applied all international product and management standards notably ISO 9001:2000 and ISO 14001:2004 in Arçelik A.Ş's eco-friendly productive facilities. The company which is the member of CECED has started to use "energy label" implementation which is the energy consumption indicator of low-energy products in the direction of instructions published by EU Commission for household electrical appliances long before the necessary date of the Turkey. Also, the first white goods producer which produced the refrigerator purged by harmful CFC gas to ozone layer much earlier than anticipated date 2006 for Turkey in Montreal Agreement is again Arçelik A.Ş (www.çevreciyiz.com).

Also, the firm called Exitcom Nature Recycling Electronic founded in 1993 in Turkey acts in gathering and processing PC and PC equipment, telecommunication equipment and printed circuit equipment in the area of computer, telecommunication and electronic recycling in Turkey and Germany (Uysal, 2007). 


\subsection{Green Marketing and Businesses}

The 1990s is named as "World's ten years" and the most important topic is seen as conservation of the natural environment. Businesses have returned to this issue with green marketing. Thus, the nature saving products development, reusable and recyclable packing, better pollution control and operations which will provide better efficiency are included in green marketing. Environmentalist marketing (green marketing) should be seen as a part of the whole environmental management and this realization is so important (Kotler and et al.1999; Akt. Keleş, 2007).

Businesses can turn the environmental problems into opportunities. For example; some natural energy sources such as energy saving in heating and lighting, low-cost wind farms and hydroelectric projects are used by businesses. Also, businesses see hundreds of green products (eco-friendly product) as an opportunity. In this context, it is encountered such examples as detergent without phosphate, recyclable engine grease, catching tuna fish without dolphin venom usage, organic fertilizer, illumination lights with high productivity, recyclable paper, $\% 100$ organic cotton, man-woman regular clothes produced with nonpoisonous color, consumer's products in small packages, decreasing the usage of paper box for deodorants and selling the tea sucks without eaves and strings (Walker and et. Al., 2003; Akt. Keleş, 2007).

Businesses that follow the green marketing agenda should fulfill some aspects such as developing presentations for protecting energy and other resources, creating advertisements and advertising messages reflecting business's environmental contributions, price selection which is going to balance consumer's cost sensibility with the higher one which they accept for ecologist product, decreasing the materials usage which cause environmental pollution and saving the resources on disposal of products (Grove and diğ. 1996).

These are expected from the business which asserts that it is related with the green marketing (Kotler and diğ., 1999; Akt. Keleş, 2007):

Evaluation the existing performance of the business in large scaled

Promising the measurement of observation, examination, reporting and recovery in the performance

Developing achievable environmental policies with open target and implementation schedule

Following the development of green agenda

Investing in education, environmental science, and technology

Helping and supporting the consumers, reclamation, supplying information with organizing educational programs to increase environment responsibility of the consumer

Preparing training programs for suppliers

Building unions and bridges among various those concerned

Contributing to environmentalist programs, great loyalty to marketing values: selling the benefit rather than products and protecting not only the product but also the company's values.

In addition to these, green marketing involves that focusing on the market, caring both known and unknown consumer needs, coordinated marketing all across of the business, planning on the long-termed profitability, having worried about environmental and social aspects of all activities and decisions, innovativeness for using opportunities about the environment and having the ability of conformance (Uydac1, 2002; Akt. Keleş, 2007).

Businesses attempt green marketing by doing one or more than one of those three activities: (1) reusing, (2) recycling and (3) reducing. The aim of these large activities formulated as " $3 R$ " in environmental management, controls the waste quantity of natural resources which are in waiting with the concerns of business's marketing. Reusing (refillable boxes), recyclable materials (used products reclamation), and reducing the resource usage (saving the energy during the production process) provide big contributions to business's positioning as pro-green in the mind of consumers and being attracted the increasing green consumer segment (Grove and diğ.,1996).

Oriental Princess which is a cosmetic firm from Thailand named the cornerstones of green marketing strategies as "4Rs". These are (Johri and Sahasakmontri, 1998):

Recycle: The firm picks up all sorts of recyclable packages. Recyclable papers are used for making paper bags and envelopes

Refill: All salesrooms give refilling service

Reuse: The firm encourages to reusing of institution related materials

Reduce: With the help of reducing, the firm reduced unnecessary packaging. The firm has placed some eco-friendly behaviors such as energy saving in the office, using the stationery equipment effectively, sharing computers and transportation. 


\subsubsection{Benefits of Green Marketing to Business}

Green marketing provides so many benefits to businesses. These benefits can be summarized as the following (Nemli, 1998):

Providing productivity in terms of environment decreases the production costs. Businesses can decrease their cost by decreasing the waste, saving the energy and reusing the materials.

Today so many consumers demand eco-friendly products, packaging, and management styles. These consumers prefer more environment conscious businesses.

When the businesses develop more idiosyncratic environment strategies which are hard to imitate, they become the leader.

Becoming eco-friendly of business in terms of public relations and an image is important and this characteristic draws more attention to the social responsibility of the business.

Environment-conscious approach decreases the long-term risks for some areas such as depletion of resources, fluctuations in energy cost, pollution and waste management

The increase in environmental performances of businesses benefits to society as well.

Health problems expenditures caused by industry pollution can be reduced

Being eco-friendly means to be under guarantee against laws.

Literature signs that environmental development will provide those external benefits to business: increasing in sales, developing customer feedbacks, being close to customers, increasing the competitiveness and developing business image (Pujari and diğ., 2003; Akt. Keleş 2007).

Besides those external benefits, businesses prefer green marketing for the following reasons: evaluating green marketing as a chance, being supported by the state and obeying the sanctions, increasing competitiveness, decreasing waste and decreasing the costs by reusing (www.paradoks.org).

In addition to these, according to study conducted by Mathur and Mathur (2000) on 73 firms, investors accept green marketing activities as a prerequisite. Also, for the businesses which have relatively better financial performance, green marketing create positive perspective and investors feel themselves better in that condition.

\subsection{Green Marketing Stages}

Green marketing consists of four stages. Respectively these stages are green targeting, developing green strategies, environmental orientation and considering the business socially responsible (Keleş, 2007).

-Green Targeting: In this stage, while green products are produced for the green consumers, business continues to product not-green products as well. For example, in the automobile industry, while hybrid, electronic cars and the ones which work with alternative technology are studied in Ar-Ge department, in the environmentalists' part, sports car seen as the reason for noise and air pollution are produced, too.

-Developing Green Strategies: Production of green and not-green products is continued. In this stage, the business tries to develop environmental strategies and determine its' environment policies. In this stage, business takes some ecologist measures such as less waste generation and increasing the energy efficiency.

-Environmental Orientation: Producing just green products after stop the not-green products production. Hence, Consumers' not-green products demands are not important.

-Considering the Business Socially Responsible: Being or getting green is not enough. The business achieves social responsibility awareness in every sense.

\subsection{Green Marketing and Traditional Marketing}

To be able to understand primary commodities of green markets, elements of traditional markets should be interpreted carefully. Traditional marketing not only specifies the number of the green consumers but also it analyzes present and future opportunities of the market. Even if some literature studies mentions consumers' needs and wishes, predominating issues in green marketing studies are the size and features of green marketing. Generally, businesses don't do with existing consumers for a product in marketing literature. They also try to reach to consumers who resistive to the product or do not realize it with the help of new communication implementations. However, consumers may not know what they exactly want. Thus, consumers' hidden and future needs should be stated by marketing people (Keleş, 2007).

The most tangible discrepancies between green and traditional marketing perspectives are in the positioning area. 
During the last ten years, eco-labels usage becomes widespread in green product positioning. The label includes some technical information about the product and it is not a promotion tool. It takes part in the marketing mix, under the "product".

In traditional marketing literature, for the product positioning, it should dwell on promotion, not on label (Keleş, 2007).

Differences between traditional and green marketing are shown in Table 1.

Table 1. Differences between Traditional and Green Marketing (Keleş, 2007)

\begin{tabular}{|c|c|c|}
\hline Criteria & Traditional Marketing & Green Marketing \\
\hline $\begin{array}{l}\text { Sides that need } \\
\text { bartering }\end{array}$ & $d_{\text {Firm }}$ and consumers & Firm, consumer and environment \\
\hline Target & $\begin{array}{l}\text { Customer Satisfaction, firm target's } \\
\text { satisfaction }\end{array}$ & $\begin{array}{l}\text { sCustomer Satisfaction, firm targets' satisfaction and } \\
\text { minimizing caused ecologic effect }\end{array}$ \\
\hline $\begin{array}{l}\text { Business } \\
\text { Responsibility }\end{array}$ & Economic Responsibility & Social responsibility \\
\hline $\begin{array}{l}\text { Marketing decisions' } \\
\text { area }\end{array}$ & From production to product usage & $\begin{array}{l}\text { All value chain from providing row material to after the } \\
\text { consumption }\end{array}$ \\
\hline Environmental Claim & Legal Necessities & Design for environment beyond the laws \\
\hline Green interest groups & Facing down and passive attitude & Starting the relations and co-operation \\
\hline
\end{tabular}

Discussion of marketing strategies in terms of green and traditional marketing and differences between them are shown in Table 2.

Table 2. Marketing Strategies in terms of Green and Traditional Marketing (Keleş, 2007)

\begin{tabular}{|l|l|l|l|l|l|}
\hline $\begin{array}{l}\text { Pazarlama } \\
\text { stratejisi }\end{array}$ & $\begin{array}{l}\text { Talep } \\
\text { ölçümü }\end{array}$ & $\begin{array}{l}\text { Segmentlere } \\
\text { ayırma }\end{array}$ & hedefleme & konumlandırma & $\begin{array}{l}\text { Rekabet } \\
\text { avantajı }\end{array}$ \\
\hline $\begin{array}{l}\text { Yeșil } \\
\text { pazarlamada }\end{array}$ & $\begin{array}{l}\text { Piyasa } \\
\text { büyükllüğü }\end{array}$ & Yeşil tüketici & $\begin{array}{l}\text { Eko-etiket } \\
\text { (ürün) }\end{array}$ & șüpheli \\
\hline $\begin{array}{l}\text { Geleneksel } \\
\text { pazarlama }\end{array}$ & $\begin{array}{l}\text { Piyasa } \\
\text { ihtiyaç ve } \\
\text { istekleri }\end{array}$ & Tüm tüketiciler & $\begin{array}{l}\text { Yer, } \\
\text { tutundurma }\end{array}$ & fiyat, mümkiün \\
\hline
\end{tabular}

\subsection{Criticisms for Green Marketing}

Johri and Sahasakmontri (1998) have stated that environmentalist concerns have decreased because of the consumer's view of "green hypocrisy" in England. Also, firms see the environmentalism as a short-term issue rather than as a long-term matter. In England, it is claimed that Body Shop continued apart from their consumers' mood adaptation and so its performance has decreased. One of the underlying reasons for the failures of environmentalist products is that making wrong decisions about the product's benefit when it is compared with real needs. In the business world, it is really hard to be able to determine the one which pollutes and the one which protects the environment. For example; a firm may have ecologist fame as well as abusing human rights because of troubles in working conditions. A firm can take part in both "the greenest" and "the most poisonous" lists. It is exceedingly hard to find sound knowledge about green activities apart from businesses' eco-friendly activities declarations to the public from their websites (Muldoon, 2006).

Consumers' who have worried about green issue buy green products, however, as a contingency effect, these buying behaviors haven't decreased the market share of green products. This situation is detected by so many literature studies. It is determined some problems such as consumer's cynicism, the complexity of the green product, green persistence and generally trust problem about green marketing. These problems come together in the core of two issues. First of all, consumers find the performances of green products are insufficient. Secondly, they are suspicious implementations. For example, claims such as "biodegradable", "recyclable" and "eco-friendly" are seen as nonproven, unconvincing and unrealistic claims (Keleş, 2007).

Pettit and Sheppard (1992) have claimed that consumers have to pay some cost while they pass from not-green products 
to green products. Each left behavior causes such costs as stress and time wasting for learning different behaviors besides its benefits. Green consuming requires some devotions. According to Pettit and Sheppard, these devotions are (1) paying more for the green, (2) spent effort for some behavior changes (washing the bottle, picking plastics and fastening, storing newspapers), (3) accepting defective replacement product for a good, (4) decreasing the consumption.

It is possible to associate marketing mix with consumers', not shopping behaviors that are the result of their green concerns. According to this (Shamdasani and diğ., 1993):

(1) Green alternatives are not better in terms of their functions,

(2) Green alternatives are so expensive,

(3) Labels, according to claim that they protect the environment are not persuasive,

(4) Finding green alternatives is really hard.

\section{Conclusion}

Today, despite taking part among scarce resources, unfortunately, necessary importance is not given to the environment. A Limited number of businesses show awareness on that issue. Although problems about the environment date back, studies about this issue still are not enough. In the same way, studies about "Green Marketing" which has come to rise recently are not enough as well.

Consequently, within the scope of rapidly-developing technology and changing world, businesses have important responsibilities about protecting the environment and producing eco-friendly green products. The business which fulfills that duty is going to be one that can survive in the future.

\section{Reference}

Ay, C., \& Ecevit, Z. (2005). Çevre Bilinçli Tüketiciler, Akdeniz Üniversitesi İ̈BF Dergisi, 10, 238-263.

Canım, F. (2015). Yerel Yönetimlerin Yeşil Pazarlama Algılama Farklılıkları Üzerine Bir Araştırma Yüksek Lisans Tezi, Karadeniz Teknik Üniversitesi, Sosyal Bilimler Enstitüsü, Trabzon.

Dereli, T., \& Baykasoğlu, A. (2002). Atıklar Ve Çevre Sorunları: Mühendislik Cephesinden Çevre Sorunlarına Bir Bakış, İletişim, 28-35.

Eren, D., \& Yılmaz, İ. (2008). Otel İşletmelerinde Yeşil Pazarlama Uygulamaları ; Nevşehir ili örneği , 13. Ulusal pazarlama kongresi, 25-29 Ekim 2008, Nevşehir Üniversitesi Ticaret ve Turizm Eğitim Fakültesi.

Grove, S. J., Raymond, P. F., Gregory, M., \& Pickett, N. K. (1996). Going Green In The Service Sector Social Responsibility Issues, Implications And Implementation, Europen Journal of Marketing, 30(5), 56-66. http://dx.doi.org/10.1108/03090569610118777

Johri, L. M., \& Kanokthip, S. (1998). Green Marketing Of Cosmetics And Toiletries In Thailand, Journal of Consumer Marketing, 15(3), 265-281. http://dx.doi.org/10.1108/07363769810219134

Keleş, C. (2007). Yeşil Pazarlama Tüketicilerin Yeşil Ürünleri Tüketme Davranışları Ve Yeşil Ürünlerin Tüketiminde Kültürün Etkisi İle İlgili Bir Uygulama. Yüksek Lisans Tezi, Çukurova Üniversitesi, Sosyal Bilimler Enstitüsü, Adana.

Kotler, P., \& Zaltman, G. (1971). Social Marketing An Approach to Planned Social Change, 35(3), 12.

Mathur, L. K., \& Ike, M. (2000). An Analysis Of The Wealth Effects Of Green Marketing Strategies, Journal of Business Research , 50, 193-200. http://dx.doi.org/10.1016/S0148-2963(99)00032-6

Muldoon, A. (2006). Where The Green Is: Examining The Paradox Of Environmentally Conscious Consumption, Electronic Green Journal, 23, 1-15.

Nemli, E. (1998). Sürdürülebilir Kalkınma Ve İşletmelerin Rolü, M.Ü. Sosyal Bilimler Enstitüsü Dergisi, 4(9).

Ottman, J., Stafford, E. R., \& Hartman, C. L. (2006). Avoiding Gren Marketing Myopia, Environment, 48(5), 22-36. http://dx.doi.org/10.3200/ENVT.48.5.22-36

Özata, Z. (2009). Yeşil Pazarlama. http://zeynepozata.wordpress.com/2006/05/10/yesilpazarlama/

Peattie, K., \& Crane, A. (2005). Green Marketing: Legend, Myth, Farce or Prophesy? Qualitative Market Research, 8(4), 357-370. http://dx.doi.org/10.1108/13522750510619733

Pettit, D., \& Jerry, P. S. (1992). It's Not Easy Being Green: The Limits of Green Consumerism in Light of the Logic of Collective Action, Queen's Quarterly, 99(2), 328-350.

Polonsky, J. M. (1994). An Introduction to Green Marketing, http://escholarship.org/uc/item/49n325b7. 
Shamdasani, P., Chon-Lin, G. O., \& Richmond, D. (1993). Exploring Green Consumers In An Oriental Culture: Role Of Personal And Marketing Mix Factors, Advances in Consumer Research, 20,488-493.

Uysal, E. (2007). Elektronik Ürünlerde Geridönüşüm ve Avrupa Birliği'nin RoHS/WEEE Direktifleri http://antrak.org.tr/genel/elektronik-urunlerde-geridonu\%C5\%9Fum-ve-avrupa-birli\%C4\%9Finin-rohsweee-direkti fleri/

This work is licensed under a Creative Commons Attribution 3.0 License. 